\title{
PEMBELAJARAN IPA BERBASIS ETHNO-STEM BERBANTU MIKROSKOP DIGITAL UNTUK MENINGKATKAN KETERAMPILAN PROSES SAINS DI SEKOLAH PERBATASAN
}

\author{
Niken Eka Priyani ${ }^{1}$ dan Nawawi ${ }^{2}$ \\ ${ }^{1}$ SD Negeri 29 Idai, Kabupaten Sintang, Provinsi Kalimantan Barat \\ ${ }^{2}$ Program Studi Pendidikan Biologi, IKIP PGRI Pontianak \\ Email: nawawi@ikippgriptk.ac.id
}

\section{Info Artikel}

Sejarah Artikel:

Diserahkan 20 Oktober 2020

Direvisi 22 Oktober 2020

Disetujui 24 Oktober 2020

\section{Keywords:}

ethno-STEM,

science process skills,

digital microscope

\section{Abstract}

The purpose of the study was to obtain an overview of the application of Science Learning Based on Ethno-STEM with Digital Microscope, and to find out how the application of Science Learning Based on Ethno-STEM in improving the Science Process Skills of fourth grade students at SD Negeri 29 Idai.

The type of research used is classroom action research (PTK) which consists of four stages in each cycle, namely planning, implementing, observing, and reflecting. The research was conducted in two cycles, each of which consisted of one meeting. The research data collection tools were the observation sheet of science process skills and student worksheets. The data analysis technique used qualitative and quantitative analysis techniques.

The results of the assessment of Science Process Skills showed that there was an increase in the ability to observe students from $45.83 \%$ to $64.58 \%$, the ability to classify students from $39.58 \%$ to $54.17 \%$, the ability to predict students from $43.75 \%$ to $56,25 \%$, the ability to submit hypotheses from $39.58 \%$ to $54.17 \%$, the ability to conclude $39.58 \%$ to $56.33 \%$, and application skills from $31.25 \%$ to $58.33 \%$. So it can be concluded that Ethno-STEM learning assisted by a simple digital microscope can improve the Science Process Skills of SDN 29 Idai students.

\section{Abstrak}

Tujuan penelitian adalah untuk mendapatkan gambaran tentang penerapan pembelajaran IPA Berbasis Ethno-STEM Berbantu Mikroskop Digital, serta untuk mengetahui bagaimanakah penerapan Pembelajaran IPA Berbasis Ethno-STEM dalam meningkatkan Keterampilan Proses Sains siswa kelas IV di SD Negeri 29 Idai.

Jenis penelitian yang digunakan adalah penelitian tindakan kelas (PTK) yang terdiri empat tahapan dalam setiap siklusnya yaitu perencanaan, pelaksanaan, pengamatan, dan refleksi. Penelitian dilaksanakan sebanyak dua siklus yang setiap siklusnya terdiri dari satu pertemuan. Alat pengumpul data penelitian adalah lembar observasi keterampilan proses sains dan lembar kerja siswa. Teknik analisis data menggunakan teknik analisis kualitatif dan kuantitatif.

Hasil penilaian Keterampilan Proses Sains menunjukkan bahwa terjadi peningkatan pada kemampuan mengamati siswa dari $45,83 \%$ menjadi $64,58 \%$, kemapuan mengklasifikasikan siswa dari $39,58 \%$ menjadi $54,17 \%$, kemampuan memprediksi siswa dari $43,75 \%$ menjadi $56,25 \%$, kemampuan mengajukan hipotesis dari 39,58\% menjadi 54,17\%, kemampuan menyimpulkan 39,58\% menjadi 56,33\%, dan keterampilan mengaplikasikan dari 31,25\% menjadi 58,33\%. Maka dapat disimpulkan bahwa pembelajaran Ethno-STEM berbantu Mikroskop digital sederhana dapat meningkatkan Keterampilan Proses Sains siswa SDN 29 Idai.

(C) 2020 Universitas Muria Kudus 


\section{Niken Eka Priyani dan Nawawi \\ PEMBELAJARAN IPA BERBASIS ETHNO-STEM BERBANTU MIKROSKOP DIGITAL UNTUK .... WASIS: Jurnal Ilmiah Pendidikan. Volume 1, Nomor 2, November 2020, hlm. 99-104}

\section{PENDAHULUAN}

Perkembangan Teknologi dan Ilmu Pengetahuan menyebabkan pendidik harus mampu beradaptasi dengan perubahan yang terjadi. Pendidik saat ini dituntut tidak hanya mampu mengembangkan kemampuan kognitif siswa, namun kemampuan yang lain terutama kemampuan dalam penyelesaian masalah dalam kehidupan sehari-hari. Keterampilan khusus yang harus mampu diajarkan oleh pendidik ini dikenal sebagai Keterampilan Abad 21 atau 21st Century Skill (P21). Menurut (Haryanti, 2018) Keterampilan Abad 21 ini terdiri dari beberapa keterampilan khusus yang akan menunjang seorang individu untuk dapat menghadapi tantangan di abad 21. Terdapat empat jenis keterampilan yang diteliti oleh USbased Partnership for 21st Century Skills (P21) yang merupakan bagian dari kompetensi individu yang dikenal dengan "The 4Cs"-communication, collaboration, critical thinking, dan creativity.

STEM merupakan singkatan dari sebuah pendekatan pembelajaran interdisiplin antara Science, Technology, Engineering and Mathematics. Sedangkan Ethno STEM itu sendiri merupakan STEM berbasis budaya atau kearifan lokal yaitu dengan lebih memanfaatkan budaya daerah setempat dalam proses pembelajaran STEM nantinya. (Azalia, 2020) STEM memungkinkan peserta didik untuk mempelajari konsep akademik secara tepat dengan menerapkan empat disiplin ilmu (sains, teknologi, keahlian teknik dan matematika). Sedangkan pembelajaran Ethno menurut Ardianti, dkk (2019) sebagai pembelajaran yang melibatkan keunggulan lokal sekitar yang dihubungkan dengan materi pembelajaran. Sejalan dengan Ismaya \& Santoso (2019) bahwa kajian budaya sekitar dapat dimasukkan dalam pembelajaran.

STEM memiliki empat ciri dan didefinisikan serta dijabarkan oleh Torlakson (2014) yakni: (1) sains yang mewakili pengetahuan mengenai hukum-hukum dan konsep-konsep yang berlaku di alam; (2) teknologi adalah keterampilan atau sebuah sistem yang digunakan dalam mengatur masyarakat, organisasi, pengetahuan atau mendesain serta menggunakan sebuah alat buatan yang dapat memudahkan pekerjaan; (3) teknik atau Engineering adalah pengetahuan untuk mengoperasikan atau mendesain sebuah prosedur untuk menyelesaikan sebuah masalah; dan (4) matematika adalah ilmu yang menghubungkan antara besaran, angka dan ruang yang hanya membutuhkan argument logis tanpa atau disertai dengan bukti empiris. Seluruh aspek ini dapat membuat pengetahuan menjadi lebih bermakna jika diintegrasikan dalam proses pembelajaran.

Pembelajaran dengan menggunakan pendekatan STEM secara langsung memberikan latihan kepada peserta didik untuk dapat mengintegrasikan masing-masing aspek sekaligus. Proses pembelajaran yang melibatkan keempat aspek akan membentuk pengetahuan tentang subjek yang dipelajari lebih dipahami. Karakter dalam pembelajaran STEM adalah kemampuan peserta didik mengenali sebuah konsep atau pengetahuan dalam sebuah kasus. Sebagaimana dalam pembelajaran IPA, maka STEM membantu peserta didik untuk menggunakan teknologi dan merangkai sebuah konsep sains. Kesimpulan tersebut didukung oleh data yang telah dikelola secara matematis.

Penguasaan bidang Science, Technology, Engineering dan Mathematics melalui pembelajaran STEM dapat dilakukan oleh pendidik melalui perpaduan konsep keilmuan yang diajarkan di kelas dengan permasalahan di dunia nyata. Siswa diharapkan mampu untuk mengaplikasikan pengetahuannya dalam lingkungan serta melalui STEM mampu memecahkan maslah, menjadi pemikir logis, serta dapat mengaitkan budaya dan kearifan lokal dengan pembelajaran.

Tujuan dari pendidikan STEM adalah agar peserta didik memiliki literasi sains dan teknologi yang nampak dari membaca, menulis, mengamati, serta melakukan sains sehingga apabila mereka kelak terjun di masyarakat, mereka akan mampu mengembangkan kompetensi yang telah dimilikinya untuk diterapkan dalam menghadapi permasalahan dalam kehidupan sehari-hari yang terkait bidang ilmu STEM (Subekti dkk, 2018).

Keterampilan Abad 21 merupakan keterampilan yang sangat dibutuhkan siswa dalam mengharapi era globalisasi saat ini. Salah satu upaya mengajarkan keterampilan Abad 21 adalah melalui penguasaan Keterampilan Proses Sains (KPS), dimana siswa dibiasakan untuk berfikir ilmiah dan terbiasa dalam berkomunikasi, berfikir kritis dan kreatif melalui penyelesaian berbagai macam permasalahan yang disajikan pendidik dalam pembelajaran di kelas. Menurut Rustaman (2003), keterampilan proses adalah keterampilan yang melibatkan keterampilan-keterampilan kognitif atau intelektual, manual dan sosial. Keterampilan 


\section{Niken Eka Priyani dan Nawawi \\ PEMBELAJARAN IPA BERBASIS ETHNO-STEM BERBANTU MIKROSKOP DIGITAL UNTUK .... WASIS: Jurnal Ilmiah Pendidikan. Volume 1, Nomor 2, November 2020, hlm. 99-104}

kognitif terlibat karena dengan melakukan keterampilan proses siswa menggunakan pikirannya. Keterampilan manual jelas terlibat dalam keterampilan proses karena mereka melibatkan penggunaan alat dan bahan, pengukuran, penyusunan atau perakitan alat. Keterampilan sosial juga terlibat dalam keterampilan proses karena mereka berinteraksi dengan sesamanya dalam melaksanakan kegiatan belajar-mengajar, misalnya mendiskusikan hasil pengamatan. Keterampilan proses perlu dikembangkan melalui pengalaman-pengalaman langsung sebagai pengalaman belajar. Melalui pengalaman langsung, seseorang dapat labih menghayati proses atau kegiatan yang sedang dilakukan.

Ilmu Pengetahuan Alam (IPA) atau sering juga disebut dengan Sains berupaya membangkitkan minat manusia agar mau meningkatkan kecerdasan dan pemahamannya tentang alam seisinya yang penuh dengan rahasia yang tidak ada habis-habisnya. BSNP (2016) menyatakan bahwa IPA berhubungan dengan cara mencari tahu tentang alam secara sistematis, sehingga IPA bukan hanya penguasaan kumpulan pengetahuan yang berupa fakta-fakta, konsep-konsep, atau prinsip-prinsip saja tetapi juga merupakan suatu proses penemuan. Sedangkan tujuan pembelajaran IPA di SD antara lain bertujuan agar siswa: 1) Mengembangkan rasa ingin tahu dan suatu sikap positif terhadap sains, teknologi dan masyarakat. 2) Mengembangkan keterampilan proses untuk menyelidiki alam sekitar, memecahkan masalah dan membuat keputusan. 3) Mengembangkan pengetahuan dan pemahaman konsep-konsep sains yang akan bermanfaat dan dapat diterapkan dalam kehidupan sehari-hari. 4) Mengembangkan kesadaran tentang peran dan pentingnya sains dalam kehidupan sehari-hari. 5) Mengalihkan pengetahuan, keterampilan dan pemahaman ke bidang pengajaran lain. 6) Ikut serta dalam memelihara, menjaga dan melestarikan lingkungan alam. Menghargai berbagai macam bentuk ciptaan Tuhan di alam semesta ini untuk dipelajari.

Sekolah perbatasan merupakan sekolah yang terletak di daerah perbatasan Indonesia dengan Malaysia, tepatnya di SD Negeri 29 Idai yang berada di Desa Idai, Kecamatan Ketungau Hulu, Kabupaten Sintang, Kalimantan Barat. Sekolah perbatasan memiliki berbagai macam permasalahan, selain infrastruktur yang kurang, listrik yang diperoleh sekolah masih berasal dari panel surya. SD Negeri 29 Idai masih dikelilingi oleh hutan Kalimantan yang memiliki berbagai hasil alam, perkebunan sawit dan perkebunan warga di antaranya kebun lada dan kopi sebagai komoditi utama. Kekayaan alam serta budaya lokal kalimantan yang masih terjaga menjadi bagian terpenting yang dapat digunakan dalam pembelajaran sains kepada siswa di SD Negeri 29 Idai .

Kesulitan belajar adalah suatu kondisi yang mana anak didik tidak belajar sebagaimana mestinya karena ada gangguan tertentu. Ketika kesulitan belajar terjadi tentu hambatan akan terjadi dalam kegiatan belajar sehingga berakibat hasil belajarnya menjadi rendah (Dimyati, 2013). Kesulitan belajar ini ditunjukkan dengan ratarata hasil belajar siswa pada materi IPA Tematik di Kelas IV masih di bawah KKM atau kurang dari 60. Pembelajaran dengan pendekatan EthnoSTEM berbasis Keterampilan Proses Sains (KPS) merupakan pendekatan pembelajaran yang dapat digunakan untuk mengatasi permasalahan siswa dan mampu menanamkan keterampilan Abad 21 bagi siswa di sekolah perbatasan.

Tujuan dari penelitian yang akan dilakukan adalah 1) Untuk mengetahui bagaimana penerapan pembelajaran IPA Berbasis Ethno-STEM Berbantu Mikroskop Digital di Kelas IV SD Negeri 29 Idai. 2) Untuk mengetahui bagaimanakah penerapan Pembelajaran IPA Berbasis Ethno-STEM dalam meningkatkan Keterampilan Proses Sains siswa kelas IV di SD Negeri 29 Idai.

\section{METODE PENELITIAN}

Penelitian yang akan dilakukan ini menggunakan metode penelitian tindakan kelas, untuk menerapkan penelitian tindakan kelas dilaksanakan melalui beberapa siklus, dimana tiap-tiap siklus terdiri dari perencanaan (planning), tindakan (action), observasi (obsevation) dan refleksi (reflection). Penelitian ini akan dilaksanakan di SD Negeri 29 Idai, Kabupaten Sintang, Provinsi Kalimantan Barat. Sampel penelitian ini adalah siswa kelas IV SD Negeri 29 Idai. Instrument pengambilan data menggunakan lembar observasi aktivitas Keterampilan Proses Sains (KPS) siswa, lembar refleksi setiap siklus. Analisis data dilakukan menggunakan analisis kualitatif dan kuantitatif

\section{HASIL DAN PEMBAHASAN}

Pembelajaran Ethno-STEM yang terintegrasikan di sekolah Dasar merupakan sebuah pembelajaran yang sangat menarik dan 


\section{Niken Eka Priyani dan Nawawi \\ PEMBELAJARAN IPA BERBASIS ETHNO-STEM BERBANTU MIKROSKOP DIGITAL UNTUK .... WASIS: Jurnal Ilmiah Pendidikan. Volume 1, Nomor 2, November 2020, hlm. 99-104}

menyenangkan bagi siswa, karena pembelajaran menjadi lebih bermakna. Penggunaan teknologi seperti mikroskop digital menjadi sebuah solusi di daerah perbatasan, dimana mikroskop ini dapat diintegrasikan dengan perangkat Handphone Android yang dimiliki oleh guru. Hasil penilaian KPS pada siklus I disajikan dalam Gambar 1 berikut.

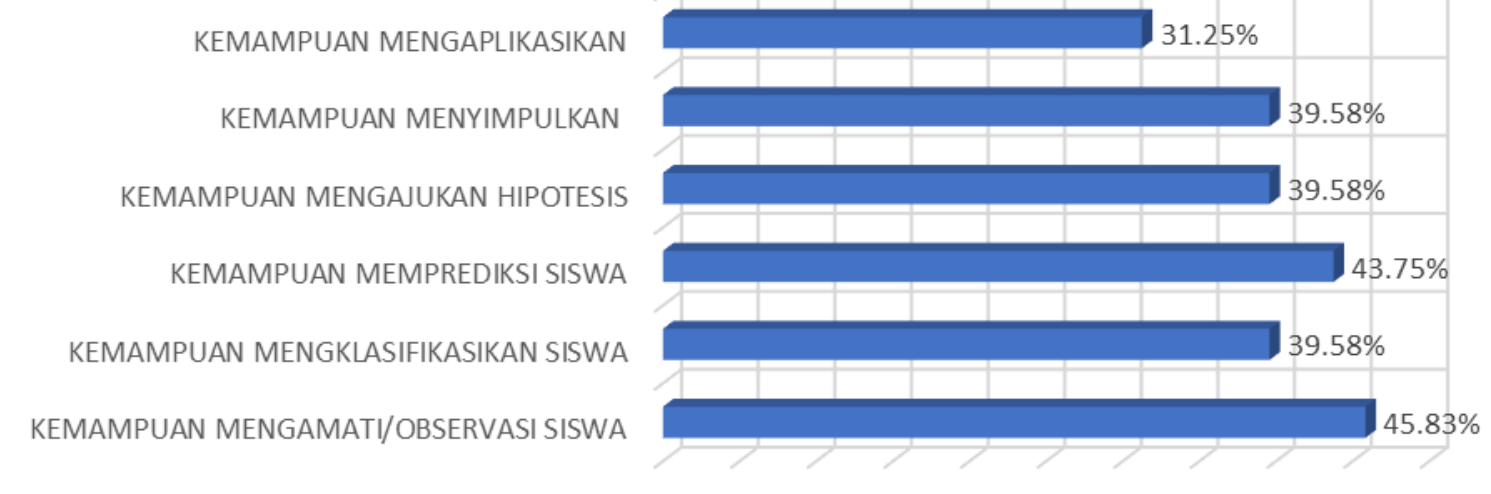

Gambar 1. Keterampilan Proses Sains (KPS) siswa pada Siklus Pertama

Berdasarkan hasil penilaian KPS (Keterampilan Proses Sains) pada siklus pertama, diperoleh beberapa informasi yaitu; 1) kemampuan siswa dalam mengaplikasikan mikroskop digital 31,25\%, 2) kemampuan menyimpulkan sebesar $39,58 \%$, 3) kemampuan mengajukan hipotesis / dugaan sementara siswa $39,58 \%$, 4) kemampuan memprediksi siswa $43,75 \%, 4)$ kemampuan mengklasifikasikan siswa $39,58 \%$, 5) kemampuan mengamati/observasi siswa $45,83 \%$. Berdasarkan hasil pengamatan pada siklus pertama, siswa kebanyakan mengalami kendala dalam mengoperasikan mikroskop digital, karena antusias yang tinggi menyebabkan setiap siswa ingin mencoba, sementara alat yang digunakan hanya 1 buah yang diintegrasikan menggunakan perangkat Handphone guru. Penggunan media yang menarik dapat membantu siswa dalam meningkatkan hasil belajar siswa (Darmawan, \& Nawawi, 2020). Berikut ini adalah bentuk dari mikroskop digital sederhana yang digunakan dalam pembelajaran.

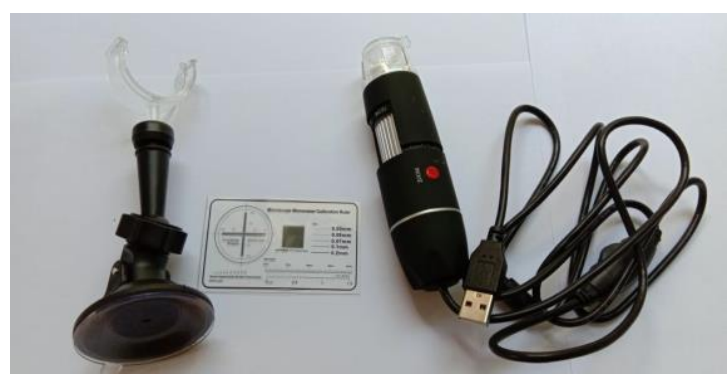

Gambar 2. Mikroskop Digital Sederhana yang digunakan untuk Pembelajaran
Kemampuan Proses Sains yang diajarkan kepada siswa kelas 4 SD Negeri 29 Idai ini adalah Keterampilan Proses Sains Dasar, dimana melalui penggunaan mikroskop digital dapat menambah kemampuan literasi teknologi siswa di daerah perbatasan Indonesia-Malaysia. Hal ini sejalan dengan penelitian yang dilakukan oleh (Dewati, Bhakti, \& Astuti, 2019) peranan micrsocope smartphone dapat meningkatkan kemampuan psikomotorik atau skill mahasiswa dalam merangkai alat untuk membantu pemahaman mereka dalam materi optik serta media microscope smartphone sangat cocok dalam pembelajaran STEM. Sedangkan penelitian Ethno-STEM yang dilakukan (Sudarmin \& Sumarni, 2018) memperoleh hasil bahwa pada motif batik yang dikembangkan mahasiswa dari pengrajin batik pekalongan telah memiliki minimal dua, tiga, atau empat komponen STEM. Ini menunjukkan bahwa pengembangan STEM dapat meningkatkan hardskill dan softskill siswa.

Dari hasil pembelajaran pada siklus pertama, diperoleh hasil bahwa siswa telah mampu untuk mengingat kembali pentingya peran tumbuhan sebagai sumber daya alam hayati dengan $100 \%$ siswa mampu menjawab pertanyaan dari guru. $100 \%$ Siswa menjadi lebih fokus dalam melakukan pengamatan terkait dengan bagian-bagian dari bunga sepatu yang dibawa siswa ke kelas. Sedangkan 58,3\% siswa belum dapat menemukan jawaban sendiri dari teks materi terkait manfaat setiap bagian tumbuhan, sedangkan $41,7 \%$ siswa telah mampu menjawab sendiri pertanyaan yang diberikan guru terkait manfaat dari bagian tumbuhan dari teks 


\section{Niken Eka Priyani dan Nawawi \\ PEMBELAJARAN IPA BERBASIS ETHNO-STEM BERBANTU MIKROSKOP DIGITAL UNTUK .... WASIS: Jurnal Ilmiah Pendidikan. Volume 1, Nomor 2, November 2020, hlm. 99-104}

materi yang telah di berikan. Hasil tersebut sejalan dengan penelitian (Novita, Pebriana, \& Astuti, 2019) bahwa pembelajaran dengan memberikan contoh nyata dapat meningkatkan Keterampilan Proses Sains Siswa. Selanjutnya dilakukan siklus II karena masih terdapat indikator yang belum terpenuhi. Adapun hasil penilaian KPS pada siklus II disajikan dalam Gambar 3 berikut ini.

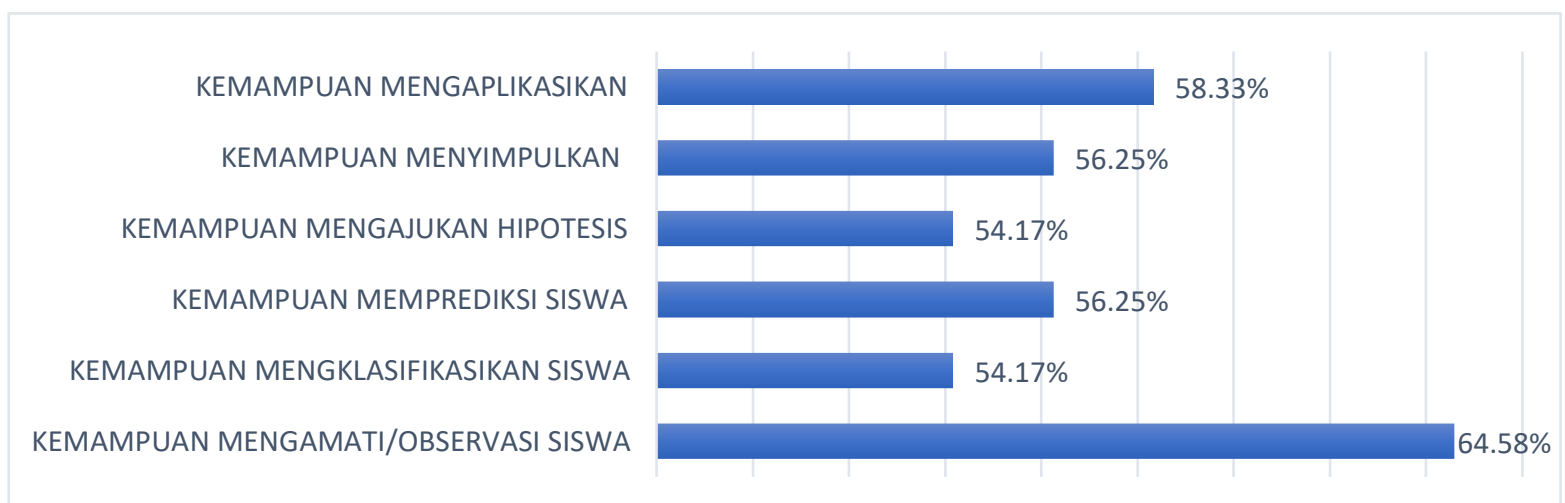

Gambar 3. Keterampilan Proses Sains (KPS) siswa pada Siklus Kedua

Berdasarkan hasil penilaian

Keterampilan Proses Sains (KPS) pada siklus kedua diperoleh beberapa informasi yaitu; 1) kemampuan mengaplikasikan 58,33\%, 2) kemampuan menyimpulkan 56,25\%, 3) kemampuan mengajukan hipotesis $54,17 \%$, 3) kemampuan memprediksi siswa $56,25 \%$, 4) kemampuan mengklasifikasikan siswa $54,17 \%, 5$ ) kemampuan mengamati atau mengobservasi $64,58 \%$.

Sedangkan berdasarkan hasil observasi yang dilakukan diperoleh hasil bahwa 58,3\% siswa belum dapat menemukan jawaban sendiri dari teks materi terkait manfaat setiap bagian tumbuhan, sedangkan $41,7 \%$ siswa telah mampu menjawab sendiri pertanyaan yang diberikan guru terkait manfaat dari bagian tumbuhan dari teks materi yang telah di berikan. Melalui pembelajaran yang dilakukan, siswa telah dapat membedakan jenis-jenis daun dikotil dan monokotil berdasarkan ciri yang disampaikan guru. Ardianti, dkk (2019) meyampaikan bahwa pembelajaran berbasis ethno dapat mempermudah siswa memahami konsep karena siswa menemukan contoh-contoh di lingkungan sekitar. Kemampuan menganalisis siswa untuk membedakan jenis-jenis daun dikotil dan monokotil diperoleh hasil $66,7 \%$ siswa, sedang $33,3 \%$ siswa belum mampu membedakan jenisjenis daun dikotil dan monokotil. Dengan menemukan jawabannya sendiri, maka konsep pembelajaran yang disampaikan akan masuk ke dalam struktur kognitif siswa sehingga informasi yang diperolehnya akan bertahan lebih lama. Hal ini sejalan dengan (Nawawi, \& Kusnoto, 2019) yang menyatakan bahwa faktor internal dan eksternal dalam belajar mempengaruhi kemampuan peserta didik dalam menyerap informasi yang diberikan oleh guru.

\section{SIMPULAN}

Berdasarkan hasil pembahasan dapat disimpulkan bahwa; 1) Pembelajaran IPA Berbasis Ethno-STEM Berbantu Mikroskop Digital Sederhana dapat menjadi model dan media pembelajaran yang efektif dalam pembelajaran siswa Sekolah Dasar, 2) Penerapan pembelajaran IPA Berbasis Ethno-STEM Berbantu Mikroskop Digital dapat meningkatkan Keterampilan Proses Sains siswa SD Negeri 29 Idai.

\section{DAFTAR PUSTAKA}

Ardianti S.D., Wanabuliandari S., Saptono S., \& Alimah S. (2019). A Need Assesment Of Edutainment Module With Ethnoscience Approach Oriented To The Love Of The Country. Jurnal Pendidikan IPA Indonesia, 8 (2): 153-161

Ardianti S.D., Wanabuliandari S., Kanzunnudin M. (2019). Implementasi Pembelajaran Berbasis Ethno-Edutainment Untuk Meningkatkan Karakter Cinta Tanah Air Siswa Sekolah Dasar. Refleksi Edukatika: Jurnal Ilmiah Kependidikan, 9 (2): 204209

Azalia, I. (2020). Pengaruh Penerapan E-Book Bermuatan Stem Terintegrasi Ethnosains 
Terhadap Keterampilan Generik Sains Peserta Didik Pada Materi Kesetimbangan Kimia (Doctoral dissertation, Universitas Negeri Semarang).

BNSP. (2016). Peraturan Menteri Pendidikan dan Kebudayaan Nomor 22 Tahun 2016 tentang Standar Proses Pendidikan Dasar dan Menengah. Jakarta: BNSP.

Darmawan, H., \& Nawawi, N. (2020). Pengembangan media pembelajaran interaktif dan lembar kerja siswa pada materi virus. JPBIO (Jurnal Pendidikan Biologi), 5(1), 27-36.

Dewati, M., Bhakti, Y. B., \& Astuti, I. A. D. (2019). Peranan Microscope Smartphone sebagai media pembelajaran Fisika berbasis STEM untuk meningkatkan pemahaman konsep Optik. In Prosiding SNFA (Seminar Nasional Fisika dan Aplikasinya) (Vol. 4, pp. 36-42).

Dimyati., Mudjiono. (2013). Belajar dan Pembelajaran, Rineka Cipta, Jakarta

Ismaya, E. A., \& Santoso, S. (2019). Tradisi Dandangan Sebagai Kajian Pembelajaran Dalam Mendukung Pencapaian Visi Universitas Kebudayaan (Studi pada Mata Kuliah Konsep Ilmu Pengetahuan Sosial). Refleksi Edukatika: Jurnal Ilmiah Kependidikan, 10(1), 128-137.

Torlakson. T. (2014). Innovate: A Blueprint For Science, Technology, Engineering, and Mathematics in California Public Education. California: State Superintendent of Public Instruction.

Haryanti, A., \& Suwarma, I. R. (2018). Profil Keterampilan Komunikasi Siswa SMP dalam Pembelajaran IPA Berbasis STEM. Wahana Pendidikan Fisika, 3(1), 49-54.

Nawawi, N., \& Kusnoto, Y. (2019). An Analysis of Online Game Influence Toward the Biology Learning Achievement of Students at SMAN 1 Suhaid and SMPN 1 Suhaid, Kapuas Hulu. Indonesian Journal of Biology Education, 2(2), 14-20.
Novita, Y., Pebriana, P. H., \& Astuti, A. (2019). Penerapan Model Example Non Example untuk Meningkatkan Keterampilan Proses Sains Siswa Sekolah Dasar. Journal on Teacher Education, 1(1), 103-116

Sudarmin, Sumarni, W .2018. IOP Conf. Ser.: Mater. Sci. Eng. The 12th Joint Conference on Chemistry.

Subekti, H., Taufiq, M., Susilo, H., Ibrohim, I., \& Suwono, H. (2018). Mengembangkan Literasi Informasi Melalui Belajar Berbasis Kehidupan Terintegrasi Stem Untuk Menyiapkan Calon Guru Sains Dalam Menghadapi Era Revolusi Industri 4.0: Revieu Literatur. Education and Human Development Journal, 3(1). 